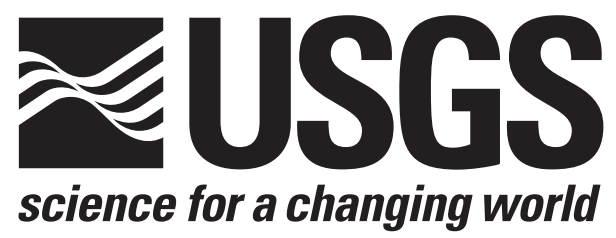

Toxic Substances Hydrology Program in cooperation with the Army Environmental Center

\title{
Ground-Water Levels near the Top of the Water-Table Mound, Western Cape Cod, Massachusetts, 2002-04
}

By Andrew J. Massey, Carl S. Carlson, and Denis R. LeBlanc

Scientific Investigations Report 2006-5054 


\section{U.S. Department of the Interior \\ Gail A. Norton, Secretary \\ U.S. Geological Survey \\ P. Patrick Leahy, Acting Director}

\section{U.S. Geological Survey, Reston, Virginia: 2006}

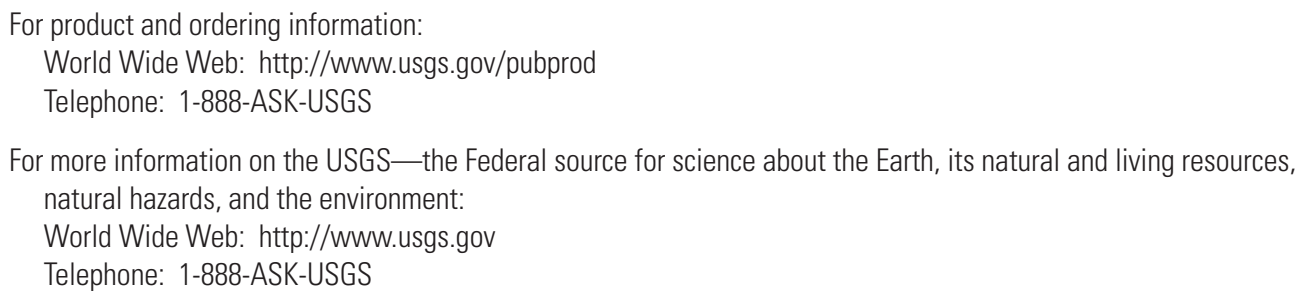

Any use of trade, product, or firm names is for descriptive purposes only and does not imply endorsement by the U.S. Government.

Although this report is in the public domain, permission must be secured from the individual copyright owners to reproduce any copyrighted materials contained within this report.

Suggested citation:

Massey, A.J., Carlson, C.S., and LeBlanc, D.R., 2006, Ground-water levels near the top of the water-table mound, western Cape Cod, Massachusetts, 2002-04: U.S. Geological Survey Scientific Investigations Report 2006-5054, 13 p. 


\section{CONTENTS}

Abstract

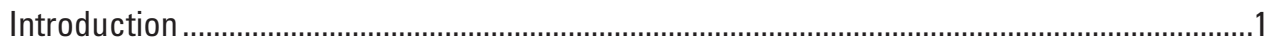

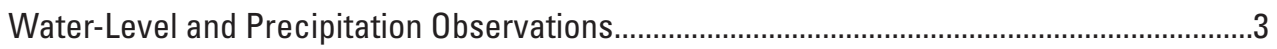

Water-Level-Monitoring Equipment................................................................................

Precipitation Measurements...........................................................................................

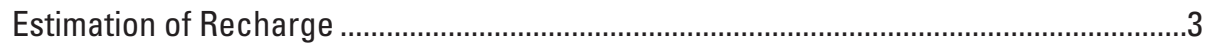

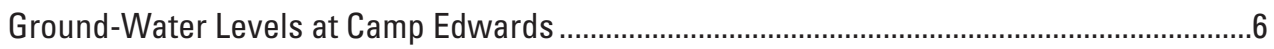

Response of Ground-Water Levels to Long-Term Precipitation Trends .........................6

Changes in Ground-Water Levels with Individual Precipitation Events ..........................7

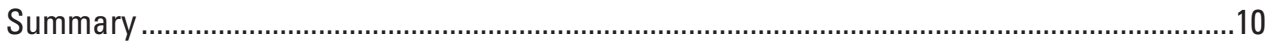

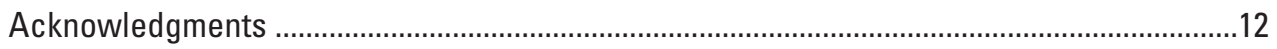

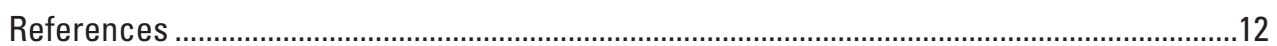

\section{FIGURES}

1. Map showing the Southeast Ranges of Camp Edwards military-training area, the simulated water table, monitoring wells, and NOAA weather stations KFMH on Otis Air National Guard Base, western Cape Cod, and at East Wareham, Massachusetts

2. Graphs showing $A$, manual measurements and hydrographs of continuous water levels recorded in three wells between the Southeast Ranges of Camp Edwards and Snake Pond, western Cape Cod; $B$, estimated daily recharge; and $C$, daily precipitation recorded at NOAA weather station KFMH on Otis Air National Guard Base, western Cape Cod, from January 9, 2002, to December 31, 2004

3-5. Hydrographs showing:

3. A, Monthly water levels measured manually in USGS well MA-SDW 253, 1962-2004, and continuously in well MA-SDW 525-0109, 2002-2004; and B, water levels measured manually in wells MA-SDW 525-0109, MA-SDW 526-0040, and MASDW 527-0055 near the Southeast Ranges of Camp Edwards at the top of the water-table mound, and in well MA-SDW 253 east of Camp Edwards, western Cape Cod, 2002-04.

4. Continuous water levels recorded in three wells between the Southeast Ranges of Camp Edwards and Snake Pond, western Cape Cod, with bar graphs of precipitation and estimated recharge, May through July 2002.

5. Continuous water levels recorded in three wells between the Southeast Ranges of Camp Edwards and Snake Pond, western Cape Cod, with bar graphs of precipitation and estimated recharge, November 2002 through January 2003. 


\section{TABLES}

1. Monitoring-well characteristics and water-level-recorder information, Camp Edwards, western Cape Cod, Massachusetts

2. Characteristics of automated water-level-recording and manual-measurement devices

3. Monthly and annual precipitation at National Oceanic and Atmospheric Administration Weather Station KFMH at Otis Air National Guard Base, western Cape Cod, 1998-2004.

4. Monthly and annual precipitation for the period 1971 to 2000 at three National Oceanic and Atmospheric Administration weather stations near Otis Air National Guard Base, western Cape Cod.

5. Estimated recharge determined from two daily soil-water balance approaches-Jensen and Haise (1963) and Thornthwaite (1948) —and annual precipitation at Otis Air National Guard Base, western Cape Cod, 2002-04 


\section{CONVERSION FACTORS AND DATUMS}

\begin{tabular}{|c|c|c|}
\hline Multiply & By & To obtain \\
\hline \multicolumn{3}{|c|}{ Length } \\
\hline inch (in.) & 2.54 & centimeter $(\mathrm{cm})$ \\
\hline inch (in.) & 25.4 & millimeter (mm) \\
\hline foot $(\mathrm{ft})$ & 0.3048 & meter $(\mathrm{m})$ \\
\hline mile (mi) & 1.609 & kilometer $(\mathrm{km})$ \\
\hline \multicolumn{3}{|c|}{ Pressure } \\
\hline pound per square inch $\left(\mathrm{lb} / \mathrm{in}^{2}\right)$ & 6.895 & kilopascal $(\mathrm{kPa})$ \\
\hline \multicolumn{3}{|c|}{ Hydraulic conductivity } \\
\hline foot per day (ft/d) & 0.3048 & meter per day $(\mathrm{m} / \mathrm{d})$ \\
\hline
\end{tabular}

Temperature in degrees Fahrenheit $\left({ }^{\circ} \mathrm{F}\right)$ may be converted to degrees

Celsius $\left({ }^{\circ} \mathrm{C}\right)$ as follows: ${ }^{\circ} \mathrm{C}=\left({ }^{0} \mathrm{~F}-32\right) / 1.8$

Vertical coordinate information is referenced to the National Geodetic Vertical Datum of 1929 (NGVD 29).

Horizontal coordinate information is referenced to the North American Datum of 1983 (NAD 83).

Altitude, as used in this report, refers to distance above the vertical datum. 


\title{
Ground-Water Levels near the Top of the Water-Table Mound, Western Cape Cod, Massachusetts, 2002-04
}

\author{
by Andrew J. Massey, Carl S. Carlson, and Denis R. LeBlanc
}

\section{Abstract}

In January 2002 the U.S. Geological Survey began continuous water-level monitoring in three wells in the vicinity of the Southeast Ranges of Camp Edwards, near the Impact Area of the Massachusetts Military Reservation on Cape Cod. The purpose of this effort was to examine how water levels at sites with different unsaturated-zone thicknesses near the top of the water-table mound beneath western Cape Cod are affected by temporally variable recharge from precipitation, which is the sole source of water to the sand and gravel aquifer. The depths to water at the well sites are about 18, 30, and 101 feet below land surface.

This report presents the first 3 years of water-level records and an estimate of aquifer recharge calculated from climatological measurements by the Jensen and Haise method and the Thornthwaite method. The water levels in the three wells varied temporally by about 4.5 feet during the study period. A comparison of the water levels with those measured in a nearby monitoring well with about 42 years of monthly measurements indicates that the 3 -year monitoring period included the lowest water levels on western Cape Cod since the drought of the 1960's. The response of water levels to recharge was related to the depth to water. Water levels in the two wells with shallow depths to water responded quickly (within hours or days) to recharge, whereas the water-level response in the well with the greatest depth to water often lagged the recharge event by a month or more. The variations in the water levels among the wells changed as the location of the top of the water-table mound moved with the changing water-table altitude.

\section{Introduction}

The aquifer system underlying Cape Cod is composed of unconsolidated sandy sediments deposited during the retreat of the continental ice sheet at the end of the Pleistocene Epoch 15,000-16,000 years ago (Oldale and Barlow, 1986). The source of all freshwater stored within these glacial sediments is precipitation that falls directly on the Cape (Strahler, 1972; LeBlanc and others, 1986). The water in the unconfined aquifer forms six mounds, or lenses, and ground water generally flows radially outward from the top of the mounds toward the coast. Surface-water bodies and pumping from wells alter this pattern in many locations (Walter and Masterson, 2003). The Sagamore Lens, the part of the aquifer that underlies westernmost Cape Cod, forms a water-table mound that rises to a maximum altitude of about $70 \mathrm{ft}$ beneath the Southeast Ranges of Camp Edwards on the Massachusetts Military Reservation (MMR) (Walter and Whealan, 2005) (fig. 1).
The U.S. Geological Survey (USGS) began systematic measurements of ground-water levels on Cape Cod in 1950 in Truro, MA. During the 1960s, in response to concerns raised by a drought in the region, several more observation wells were installed to monitor water levels in the aquifer. In 1972, the Association to Preserve Cape Cod placed staff gages in kettle ponds across the Cape to monitor pond levels. The USGS mapped the Cape Cod water table in detail in 1975-77 as part of an assessment of the ground-water resources (LeBlanc and others, 1986). In 1982, the U.S. Environmental Protection Agency designated Cape Cod as a "sole source aquifer" in recognition of the fact that precipitation falling directly on the Cape is the only source of freshwater. The designation highlighted the importance of protecting areas for recharge (Ryan, 1980).

During the late 1990s, ground-water-flow models were developed to delineate the contributing areas for proposed and existing public water-supply wells on western Cape Cod (Masterson and others, 1998). Walter and Masterson (2003) used a ground-water-flow model of the western part of the Sagamore Lens to demonstrate that the location of the top of the mound, and therefore flow direction, changed as water levels changed seasonally and from year to year.

In January 2002, the USGS, in cooperation with the Army Environmental Center (AEC) at the MMR, began continuous monitoring of ground-water levels in three wells near the top of the water-table mound to support ongoing studies by the AEC Impact Area Groundwater Study Program (IAGWSP). These studies relate military activities at the MMR with the chemical signatures of explosives and other ordnance-related contaminants that have been detected in ground water near the MMR. The monitoring period included a drought that had begun in 2001 (Air Force Center for Environmental Excellence, 2003). During the drought, the water table declined to levels not observed since the 1960s. The relation between the timing and magnitude of precipitation, estimated recharge, and changes in water levels at different locations near the top of the water-table mound beneath western Cape Cod were investigated on the basis of the measurements.

This report presents water-level data collected with digital recorders at three observation wells near the top of the mound during the 3-year period January 2002-December 2004, and illustrates differences in the responses of the water levels to recharge for a range of unsaturated-zone thicknesses. Water levels observed in the wells during the period were also compared to the water levels at a nearby well with more than 40 years of record. 


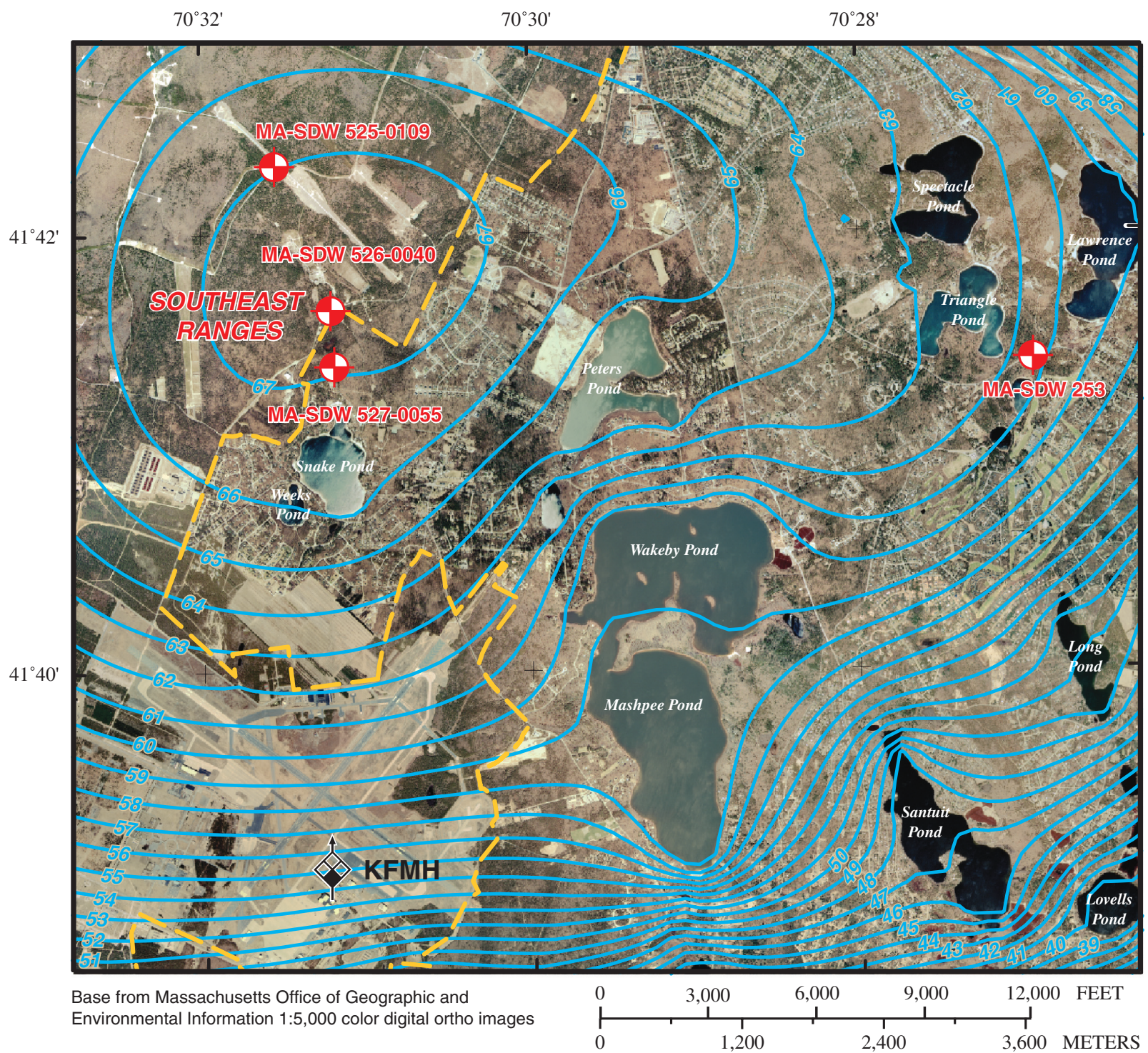

\section{EXPLANATION}

WATER-TABLE CONTOUR - Shows simulated altitude of water table, in feet above NGVD 29. Contour interval is 1 foot (Walter and Whealan, 2004)

\section{MASSACHUSETTS MILITARY RESERVATION BOUNDARY}

MA-SDW 527-0055

MONITORING WELL AND NUMBER

KFMH OTIS AIR BASE WEATHER STATION

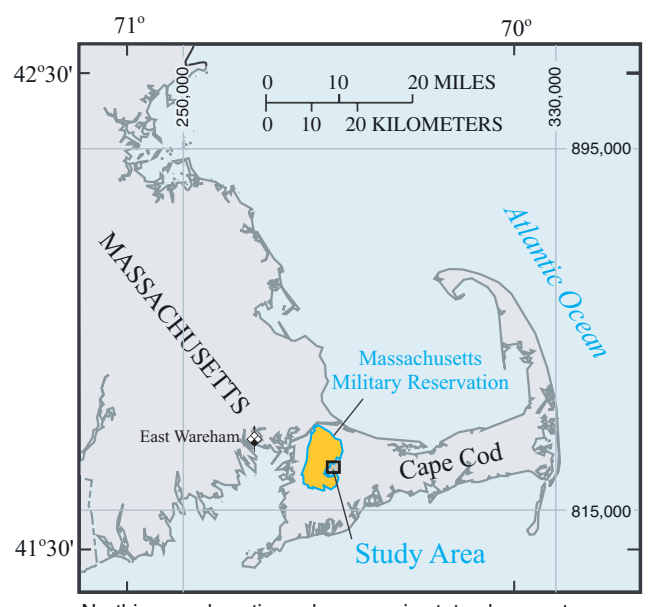

Northings and eastings shown are in state plane meters. State Plane Coordinate System Datum is NAD 83

Figure 1. Southeast Ranges of Camp Edwards military-training area, the simulated water table, monitoring wells, and the locations of NOAA weather stations KFMH on Otis Air National Guard Base, western Cape Cod, Massachusetts, and at East Wareham, Massachusetts. 


\section{Water-Level and Precipitation Observations}

Water-level data and daily precipitation records were examined to determine the relation between precipitation and changes in the water levels. Water-level data were collected from three previously installed observation wells near the top of the water-table mound. The wells are in the same general area near the Southeast Ranges of Camp Edwards, have different depths to water, and have construction characteristics that are favorable for continuous monitoring of water levels (table 1). The depths to water, or unsaturated-zone thickness, at the wells are representative of the range of depths to water on most of western Cape Cod, and vary spatially because of the undulating topography associated with the glacial origin of the Cape.

Daily precipitation data from the National Oceanic and Atmospheric Administration (NOAA) Weather Station, KFMH, at Otis Air National Guard Base (ANGB), Mashpee, $\mathrm{MA}$, was used in this investigation. This data set also was used to compute an estimate of recharge. Missing data from weather station KFMH were estimated from NOAA records from the nearby East Wareham, MA, weather station.

\section{Water-Level-Monitoring Equipment}

The water-level-recording device used in this study was the In-Situ MiniTROLL. The MiniTROLL includes a downhole pressure sensor and datalogger suspended at a fixed depth by a data-retrieval cable with a coaxial vent tube. The device was suspended below the water surface in each well within the range recommended by the manufacturer. Periodic measurements of the depth to water were made manually with a Slope Indicator electrical water-level tape to check the operation of each continuous-recording device. Manufacturer specifications for the devices are listed in table 2. The ground-water-level data are available from the USGS Massachusetts-Rhode Island Water Science Center http://ma.water.usgs.gov.

\section{Precipitation Measurements}

Precipitation and temperature data were obtained from NOAA weather stations close to the observation wells (tables 3 and 4). Otis Weather Station KFMH is adjacent to the airfield control tower at Otis ANGB, about 3 mi south of the observation wells (fig. 1). A contractor to the Air National Guard operates the station to assist with flight operations. The climatological data are available from the Northeast Regional Climate Center at Cornell University, Ithaca, NY (Northeast Regional Climate Center, 2005) or in a provisional format online from NOAA National Weather Service daily climate data-retrieval site (National Oceanic and Atmospheric Administration, 2005).

\section{Estimation of Recharge}

Precipitation that falls onto Cape Cod either evaporates from the land surface, is transpired by plants, falls directly into surface-water bodies, or infiltrates into the permeable ground. Very little water remains at the surface as overland flow on Cape Cod (LeBlanc and others, 1986). If the shallow soil is dry enough, some infiltrated water may be retained, where it can be taken up subsequently by plant roots and transpired. Water that moves below the root zone continues moving downward through the unsaturated zone and recharges the aquifer at the water table. Antecedent soil-moisture conditions determine whether or not water from a given rainfall event recharges the aquifer. The time between rainfall and corresponding recharge at the water table is controlled by many factors, including the antecedent soil-moisture conditions, the thickness of the unsaturated zone, and the hydraulic characteristics of the soil. Because only a portion of the precipitation recharges the aquifer, an estimate of daily recharge was made for comparison to the observed water levels (fig. 2).

Daily recharge was estimated for an 8-year period (calendar years 1997-2004) by using a soil-water balance approach (Thornthwaite and Mather, 1957) with inputs of daily measured precipitation, soil-moisture capacity (SMC), and daily estimated potential evapotranspiration (PET). Soil-moisture capacity is the quantity of moisture retained in the soil after excess moisture is drained through gravity drainage. The initial 5-year period (1997 to 2001) was included to ensure that effects of the estimated initial soil moisture used to start the calculations had diminished and that at least one yearly waterbudget cycle was balanced before calculations for the 3-year study period began (Thornthwaite and Mather, 1957).

The PET estimates were obtained by two methods (Jensen and Haise, 1963; and Thornthwaite, 1948) from climatological data (maximum and minimum daily temperature, and daily solar radiation) measured at the Otis Weather Station. SMC values of 4 and 6 in., assumed to be reasonable for the sandy soils of Cape Cod (LeBlanc and others, 1986), were used in the analysis. The value used for SMC can affect the quantity of water available for recharge. If the amount of moisture in a soil is below the SMC, the soil-moisture deficit-the difference between the SMC and the quantity of soil moisture-must first be satisfied in the soil-water-balance calculation before water is available for recharge. The amount of water in the soil column that is in excess of the SMC after accounting for PET is water available for recharge.

Jensen and Haise (1963) developed an energy-balance approach for estimating PET on the basis of temperature and solar-radiation data. The Jensen and Haise PET estimates were calculated by using a graphical interface program called WDMUtil (Hummel and others, 2001) that allows users to import and operate on meteorological data files. WDMUtil contains algorithms to calculate daily PET by the Jensen and Haise (1963), Hamon (1961), and Penman (1948) methods. 
Table 1. Monitoring-well characteristics and water-level-recorder information, Camp Edwards, western Cape Cod, Massachusetts.

[MMR, Massachusetts Military Reservation; USGS, U.S. Geological Survey; ID, identification number; altitudes and depths in feet relative to NGVD 29]

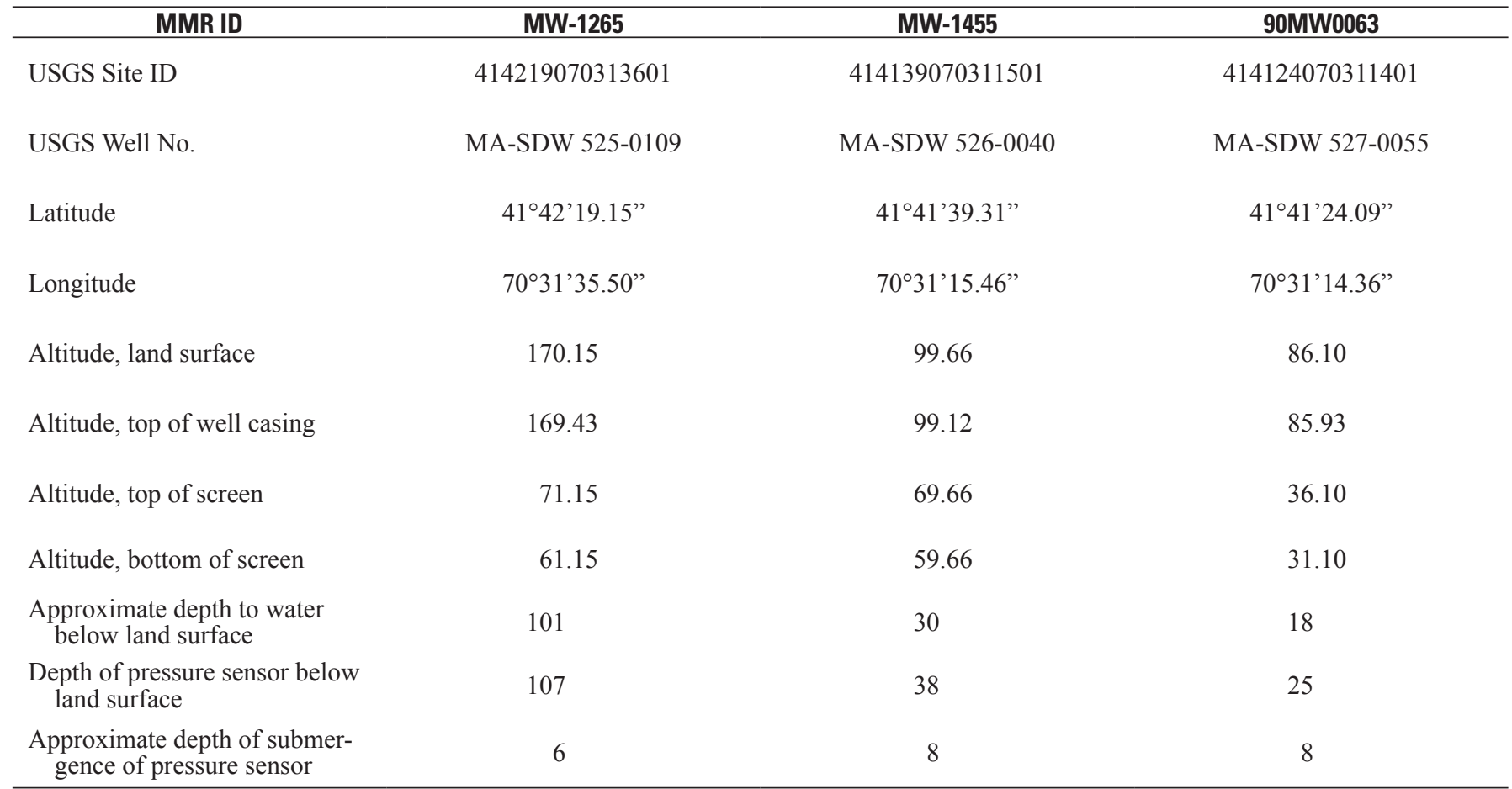

Table 2. Characteristics of automated water-level-recording and manual-measurement devices.

[psig, pounds per square inch gage; in., inch; ft, feet; psi, pounds per square inch]

\begin{tabular}{lc}
\hline & Descriptor \\
\hline Device type & In-Situ MiniTROLL \\
Make and model & Submersible pressure transducer, data logger, vented cable \\
Specifications & In-Situ MiniTROLL, internal power, 30 psig \\
Pressure sensor & 11.65 -in. long, 0.72-in. diameter, 69-ft measurement range \\
Range and accuracy & Silicon strain-gage \\
Measurement frequency & 30 psi (69 ft), 0.1\% full scale \\
& 30 minutes (adjustable) \\
\hline Make and model & Water-level tape \\
Specifications & Sinco Slope Indicator electrical water-level tape \\
\hline
\end{tabular}



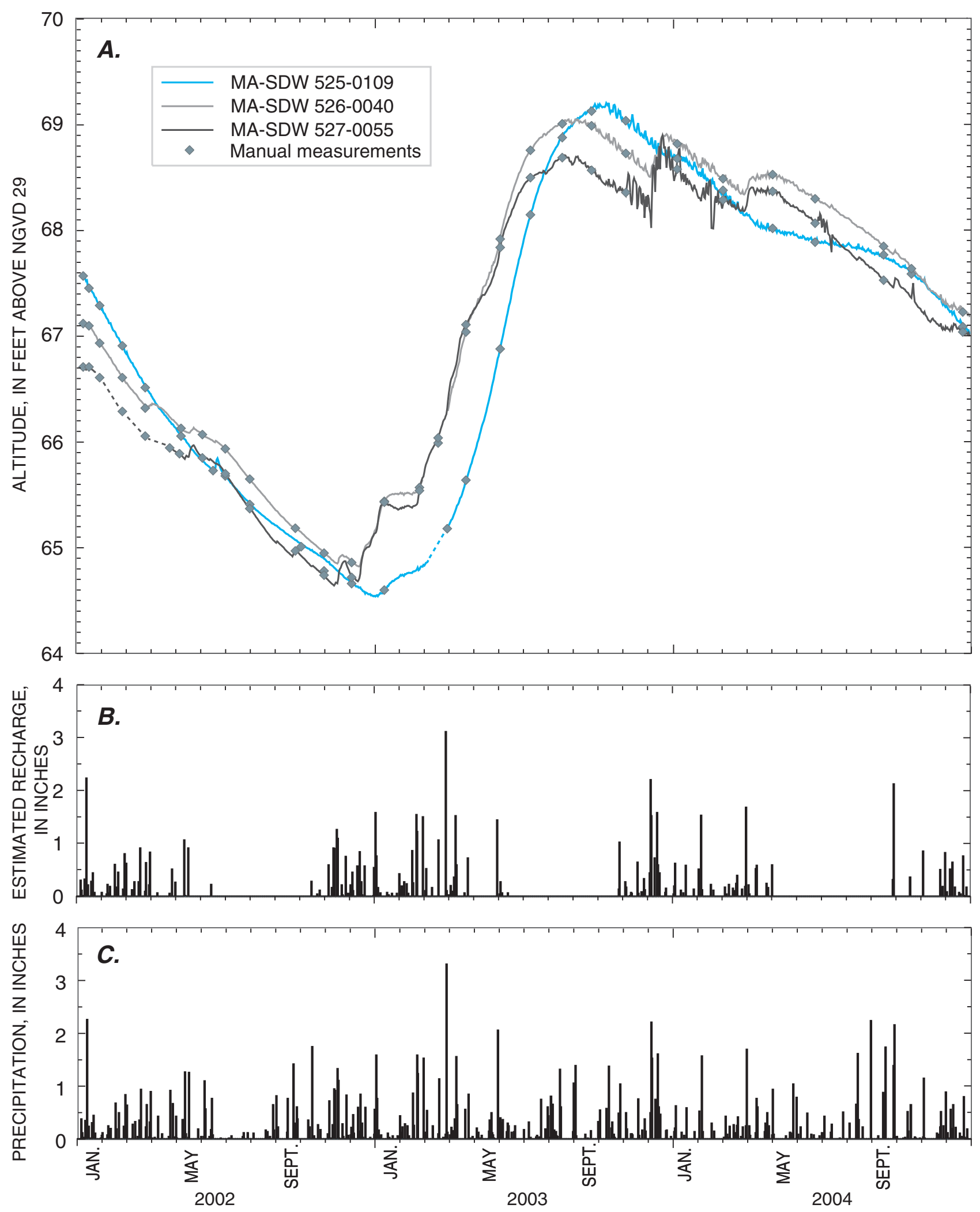

Figure 2. A, Manual measurements and hydrographs of continuous water levels recorded in three wells between the Southeast Ranges of Camp Edwards and Snake Pond, western Cape Cod; B, estimated daily recharge; and C, daily precipitation recorded at NOAA Weather Station KFMH on Otis Air National Guard Base, western Cape Cod, Massachusetts, from January 9, 2002, to December 31, 2004. Dashed lines indicate gaps in the record during periods of equipment malfunction. 
The Jensen and Haise method uses minimum and maximum daily temperature, daily solar radiation, and two calculated coefficients. The daily PET estimates calculated by the WDMUtil program, the daily precipitation, and a value for SMC were used as input to a separate FORTRAN program that calculated a daily soil-water balance based on the method of Thornthwaite and Mather (1957). This program uses the soil-moisture value from the previous day to calculate the daily water-balance for the current day using precipitation and PET. Estimates of daily recharge are the result.

The second method used to estimate PET was developed by Thornthwaite (1948) and uses an empirical approach on the basis of temperature and day-length estimates. The Thornthwaite approach is used in a FORTRAN computer program called WATBUG (Willmott, 1977), which calculates daily or monthly water budgets. Daily calculations use average daily temperature, latitude, daily precipitation, and a value for SMC as input. In this water-balance program, daily temperature and latitude data were used to calculate daily Thornthwaite PET. WATBUG computes a daily accounting of precipitation, PET, and soil moisture to calculate a daily recharge estimate.

Recharge estimates based on the Jensen and Haise and Thornthwaite PET methods are similar. The average annual recharge estimates for the entire study period 2002 to 2004 based on the Thornthwaite PET method for SMCs of $4 \mathrm{in}$. and $6 \mathrm{in}$. were $24.5 \mathrm{in} / \mathrm{yr}$ and $23.5 \mathrm{in} / \mathrm{yr}$, respectively; recharge estimates by the Jensen and Haise PET method for SMCs of $4 \mathrm{in}$. and $6 \mathrm{in}$. were slightly lower, $24.3 \mathrm{in} / \mathrm{yr}$ and $22.7 \mathrm{in} / \mathrm{yr}$, respectively (table 5). Yearly recharge estimates for both PET methods were slightly lower for SMC of 6 in. (about 3 to 11 percent) than recharge estimates for a SMC of 4 in. (table 5).

These recharge estimates are similar to those reported by LeBlanc and others (1986) despite the different periods of record. LeBlanc and others (1986) used the Thornthwaite and Mather (1957) method to estimate an average annual recharge rate of about $20 \mathrm{in} / \mathrm{yr}$ for the period 1961 to 1976 for several locations on Cape Cod, and 22.6 in/yr for the period 1947 to 1976 for East Wareham, MA. Average annual precipitation was about 44 in. for the period 1961 to 1976 for Cape Cod, MA, and 43.7 in. for the period 1947 to 1976 for East Wareham, MA. Average annual precipitation recorded at the Otis Weather Station for 2002 to 2004 was 42.7 in. The annual precipitation in 2003 was 51.30 in. (table 3) whereas the estimated 30-year average annual precipitation for the region surrounding the wells is 46.6 in (table 4). The greater recharge estimate for 2002-04 than for 1961-76 probably reflects the substantially higher-than-average precipitation in 2003 (table 3).

Because the Jensen and Haise PET method uses a greater variety of available measured data than the Thornthwaite method, and the recharge values for the two values of SMC are similar, daily recharge estimates based on the Jensen and Haise PET method with a SMC of 4 in. are used in this report for comparison to the ground-water levels.
The rates of recharge presented in this report help illustrate the relation between precipitation and ground-water levels, but the estimates are uncertain for several reasons. The PET estimates are based on empirical methods that have not been field-verified by independent methods on Cape Cod. Other methods would likely yield different results. The soilwater-balance method only approximates complex hydraulic processes, including the important effect of SMC, in the soil zone. Finally, the climatological data were collected at a site about $3 \mathrm{mi}$ from the wells (fig. 1), and these data could differ from the corresponding values at the well sites.

\section{Ground-Water Levels at Camp Edwards}

The altitude and shape of the water table beneath Cape Cod vary with time because of the dynamic balance between recharge from inflows, including precipitation and wastewater disposal; and outflows, including ground-water flow to the coast and streams, and water pumped from wells. Therefore, the top of the water-table mound generally falls during dry periods and rises during wet periods. Additionally, the location of the top of the mound moves as water levels rise and fall (Walter and Masterson, 2003).

Soil-moisture conditions, evaporation, interception, and plant transpiration play major roles in controlling the amount of water that passes from the land surface through the unsaturated zone to recharge the aquifer. Precipitation falling during the summer or after a prolonged dry period may contribute less recharge than an equivalent volume of precipitation during other times of the year. The thickness of the unsaturated zone also plays a role in controlling the timing of the response of water levels to recharge.

\section{Response of Ground-Water Levels to Long-Term Precipitation Trends}

Annual precipitation is, on average, evenly distributed over the year, but can vary substantially from year to year. During the 4-year period May 1998 through summer 2002, precipitation was as much as 60 percent below normal (table 3). As a result, when continuous recording of water levels began in January 2002, the region was already in a drought. Water levels in wells near the top of the water-table mound were declining steadily and declined an additional 2-3 ft from January to October 2002 (fig. 2A).

USGS observation well MA-SDW 253, near Triangle Pond in Sandwich, MA, about 3.5 miles east of the MMR, is screened in the same aquifer as the wells used in this study (fig. 1). The historical range (1963-2004) in water-level fluctuation at this well is about $10 \mathrm{ft}$. The hydrographs for the three study wells correspond closely to the hydrograph for well MA-SDW 253 during the period 2002-04 (fig. 3). The ground-water level at well MA-SDW 253 in November 2002 was only $0.32 \mathrm{ft}$ above the record-low level observed at this site in 1967 (fig. 3A). Therefore, it is likely that the hydrographs of the three wells captured the most severe period of 
drought since the 1960s. This comparison also suggests that the water levels in the study wells can be expected to fluctuate about $10 \mathrm{ft}$ between extreme low and high levels.

Weather patterns changed in November 2002 and brought greater-than-normal rainfall and recharge; almost $7 \mathrm{in.} \mathrm{of} \mathrm{pre-}$ cipitation was recorded at the Otis Weather Station during that month (table 3). As a result, water levels in the wells began to rise. Rising water levels were observed first in the well with the shallowest depth to water (MA-SDW 527-0055) (fig. 2A). The water level began to rise shortly thereafter in the well with the intermediate depth to water (MA-SDW 526-0040). About a month later, water levels began to rise in the well with the greatest depth to water (MA-SDW 525-0109).

Slightly above average precipitation (table 3 ) continued during 2003. An annual total of $51.30 \mathrm{in}$. was recorded at the Otis Weather Station, even though May and July were relatively dry months with 1.93 and 1.54 in. of rainfall, respectively (table 3 ). This increased precipitation resulted in substantial recharge through June 2003. Water levels rose rapidly in all three wells through this period. Recharge to the aquifer decreased despite the rainfall, however, as the summer growing season began. The hydrographs began to level off for the shallowest well (MA-SDW 527-0055) first. Soon thereafter, the hydrograph for the intermediate well (MA-SDW 5260040) began to flatten. About 1.5 months later, the deepest well (MA-SDW 525-0109) followed the same pattern. Water levels in all three wells rose more than $4 \mathrm{ft}$ during the first half of the year, and with water levels at or slightly above their long-term averages at wells across the region (for example, MA-SDW 253), it was clear that the drought had ended.

While rebounding from the drought, water levels in the three wells rose almost continuously from March to August 2003 at an average rate of about $0.64 \mathrm{ft}$ per month $(0.021 \mathrm{ft} / \mathrm{d})$ (fig. 2A). During this period, the levels rose about $4.5 \mathrm{ft}$, and the total estimated recharge was about $1 \mathrm{ft}$. If the rise was directly proportional to the amount of recharge, the estimated specific yield is about 0.2 , which is a reasonable value for sand and gravel.

Little recharge was produced by precipitation in summer 2003; therefore, water levels began to decline slowly (fig. 2). This is the normal seasonal pattern for this area. Substantial recharge began again in late October 2003 at the end of the growing season, and continued through the winter. Some precipitation fell as snow during the study period and was frozen at the surface; however, snow and ice generally persist for only short periods on Cape Cod except during extended cold periods. Windy conditions over a frozen snowpack can contribute to substantial moisture loss through sublimation (Fassnacht, 2004). This loss of potential recharge is not considered in this report.

The water-level altitudes in the three wells changed relative to one another several times during the study period (fig. 2A) The water-level altitude at well MA-SDW 525-0109 changed from the highest to the lowest among the three wells in the spring and summer of 2002, and remained the lowest until July 2003. During periods of low water levels, it appears that the water table at this well, which is about 1 mi north of the other two observation wells (fig. 1), declines to the lowest altitude among the three wells. However, during times of high water levels resulting from periods of increased recharge, the water table at this northernmost well rises to the highest altitude among the three wells. Data from summer 2003 indicate that the water level in well MA-SDW 525-0109 was steadily rising and, by early September 2003, again was highest among the three wells (fig. 2A).

The change in relative water-table altitudes among the wells indicates a southeastward shift of the top of the watertable mound when water levels are low, such as fall 2002, and a gradual northwestward shift when water levels rise regionally, during 2003 for example. The phenomenon is complicated by the lag in response to recharge due to the thick unsaturated zone at well MA-SDW 525-0109, but ultimately, when water levels are high (early 2002 and late 2003 are two examples (fig. 2)), the mound shifts to the northwest. This relation is consistent with ground-water-flow simulations (Walter and Masterson, 2003) that indicate that the top of the mound moves along a line generally oriented northwest to southeast as regional water levels fluctuate.

\section{Changes in Ground-Water Levels with Individual Precipitation Events}

Several general relations were evident from the comparison of water levels to recharge estimated from precipitation and climate records. Because of the dry period preceding installation of the measuring equipment, the amount of recharge reaching the water table from precipitation was insufficient to reverse the declining water-level trend observed throughout most of 2002. During a 9-day period starting on May 10, 2002, however, 3.3 in. of rain fell (fig. 4), with more than 2 in. falling over the first 5 days of the period. The water level in well MA-SDW 527-0055, the well with the shallowest depth to water, began to rise on about May 13, probably in response to the recent rain and an estimated 1.06 in. of recharge from the $1.6 \mathrm{in}$. of rain on May 13. The rate of water-level decline in well MA-SDW 526-0040, the well with an intermediate depth to water, decreased to near zero at about the same time, and by May 18, after an additional 1.25 in. of rain ( $0.92 \mathrm{in.} \mathrm{of} \mathrm{recharge),} \mathrm{the} \mathrm{water} \mathrm{level} \mathrm{in} \mathrm{this} \mathrm{well} \mathrm{began}$ rising. In contrast, the water level in MA-SDW 525-0109, the well with the greatest depth to water, continued to decline until mid-June, when water levels rose briefly, perhaps in response to recharge from the mid-May precipitation. This would indicate a 1-month time lag between the mid-May recharge events and the response of the water level at the site.

Although water levels in the three wells rose in apparent response to the substantial precipitation in May 2002, precipitation and water-level rises were only weakly correlated in this study (fig. 2) because the amount of recharge that results from a given storm is affected by evapotranspiration rates and antecedent soil-moisture conditions. For example, the storms in June 2002 (fig. 4) appear to have resulted in little or no 

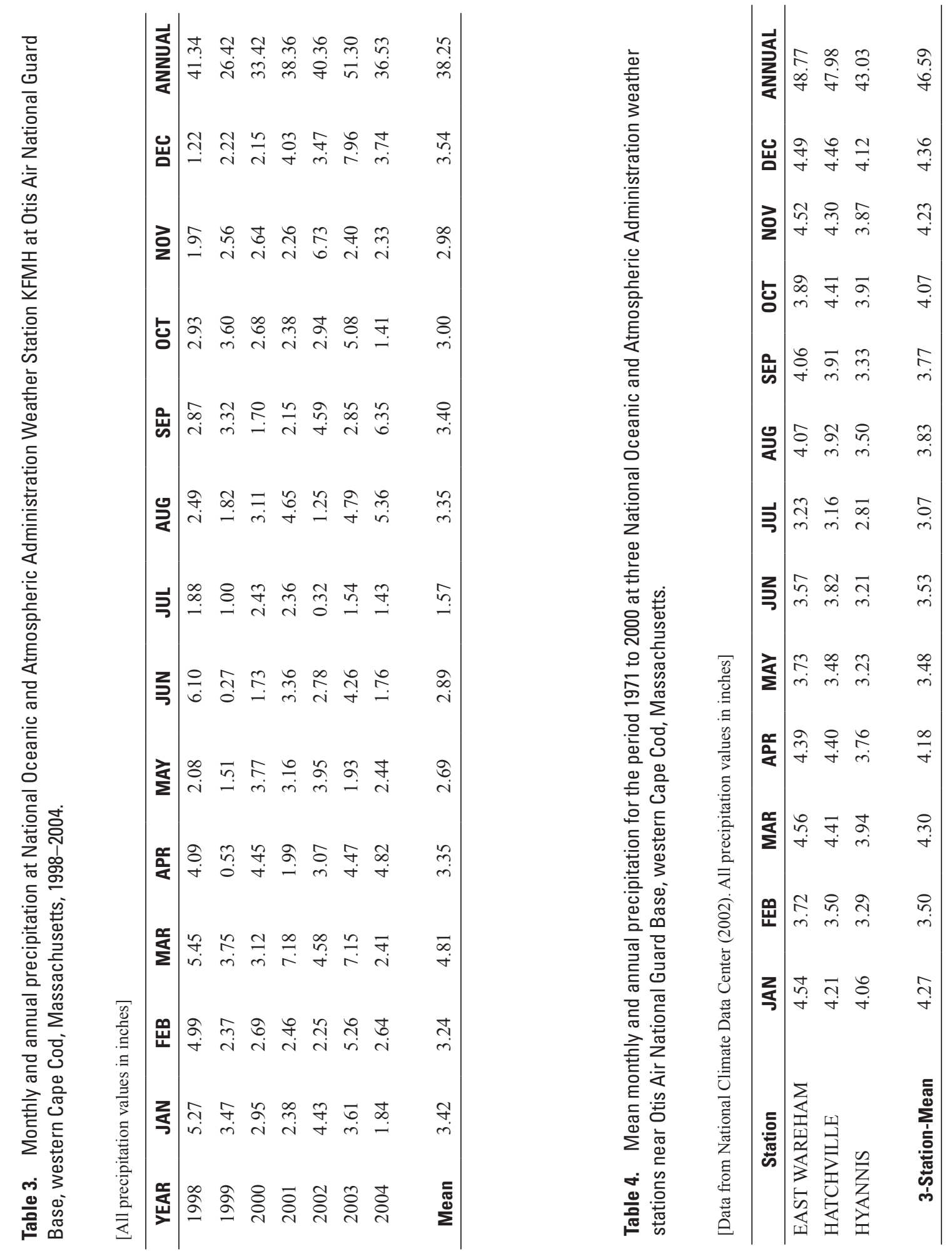

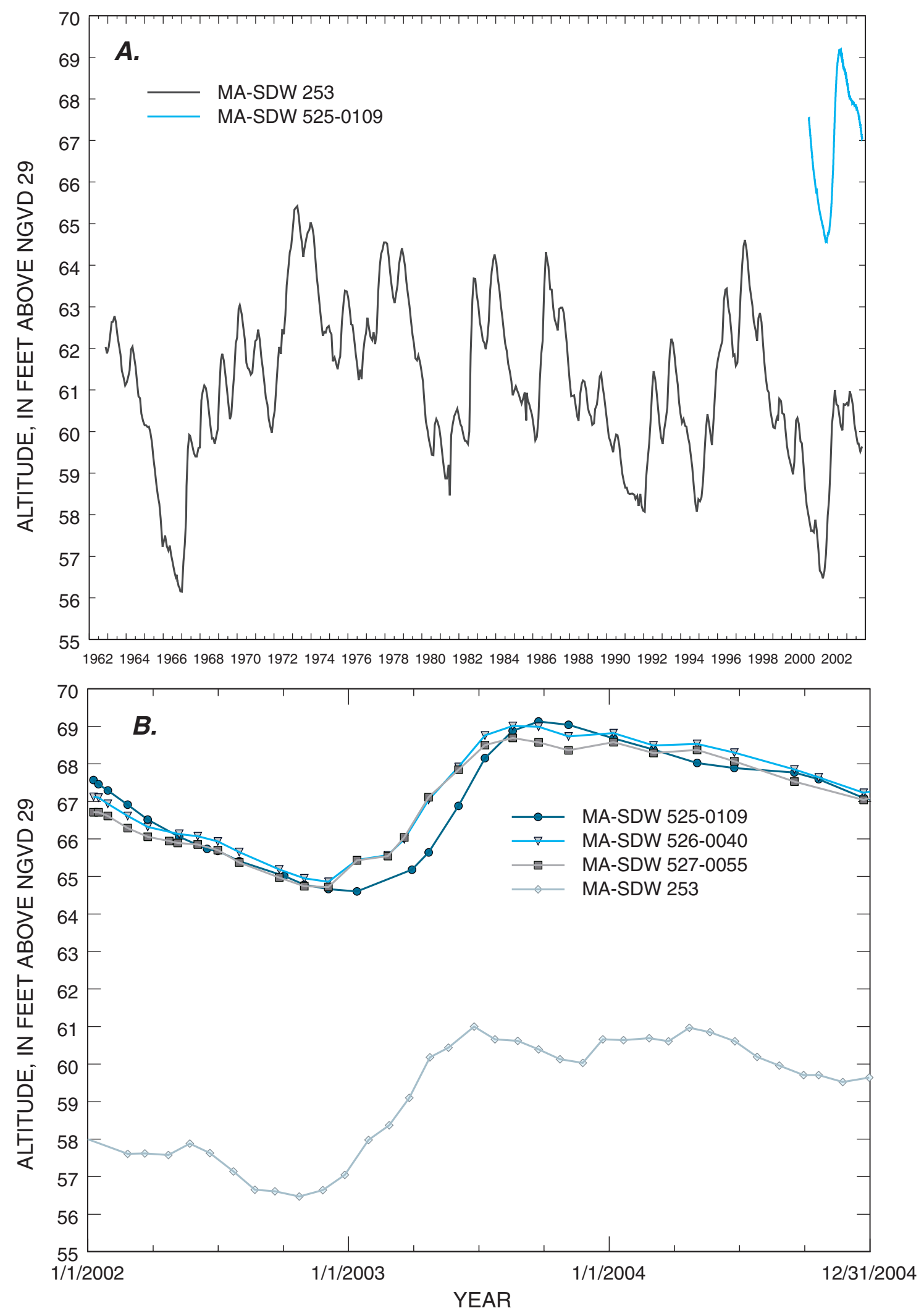

Figure 3. A, Monthly water levels measured manually in USGS well MA-SDW 253, 1962-2004, and continuously in well MASDW 525-0109, 2002-2004; and B, water levels measured manually in wells MA-SDW 525-0109, MA-SDW 526-0040, and MASDW 527-0055 near the Southeast Ranges of Camp Edwards at the top of the water-table mound, and in well MA-SDW 253 east of Camp Edwards, on western Cape Cod, Massachusetts, 2002-04. 


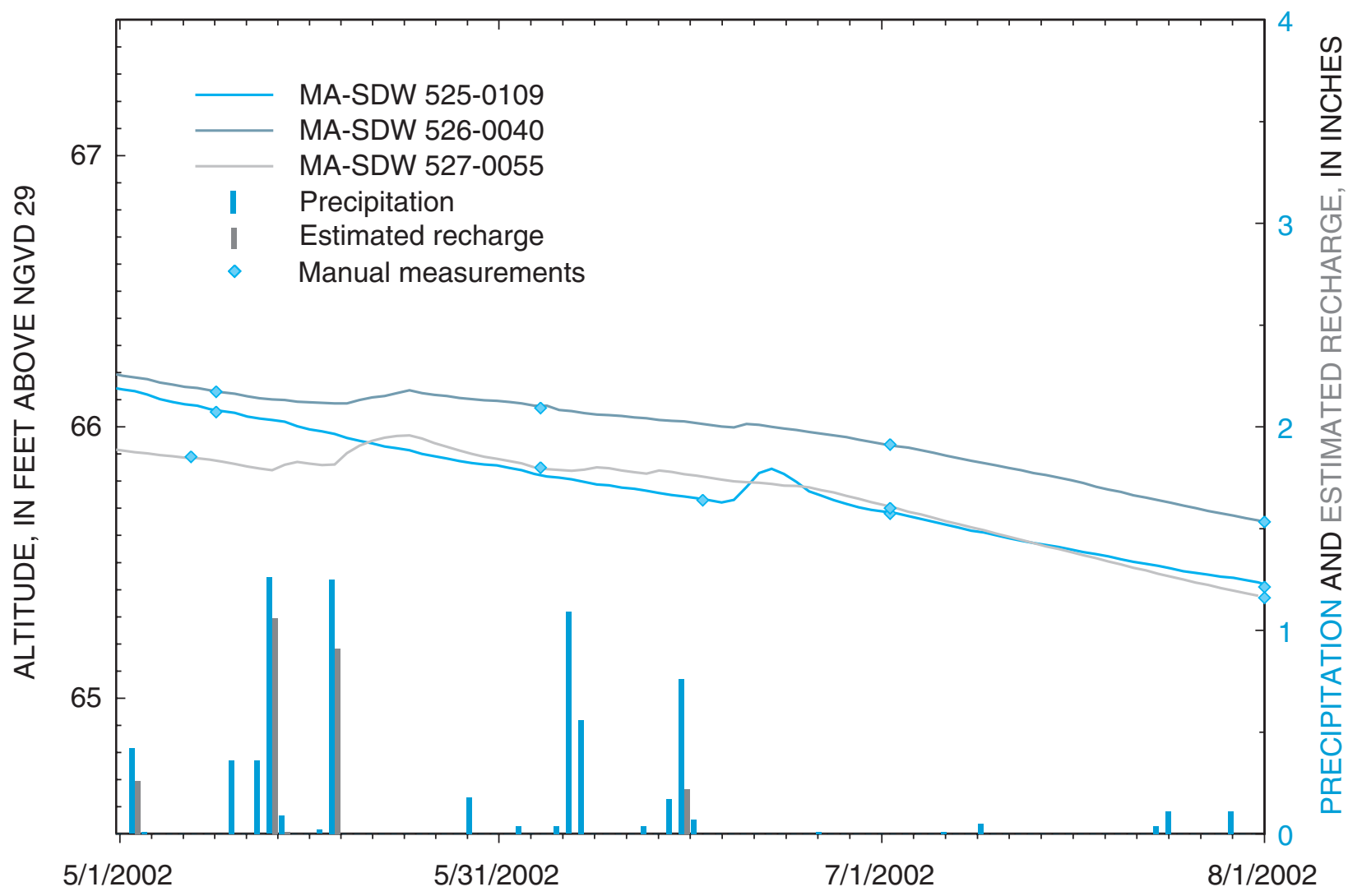

Figure 4. Continuous water levels recorded in three wells between the Southeast Ranges of Camp Edwards and Snake Pond, western Cape Cod, with bar graphs of precipitation and estimated recharge, May through July 2002. Daily precipitation was recorded at NOAA Weather Station KFMH at Otis Air National Guard Base, western Cape Cod, Massachusetts.

recharge because of substantial direct evaporation to the atmosphere, increased transpiration by plants, and further replenishment of soil moisture. Therefore, water levels declined throughout the summer and early fall 2002, despite normal rainfall in August and September 2002 (fig. 2).

In late 2002, several frequent precipitation events contributed substantial recharge. The recharge estimate for this time period suggests that nearly all of the incoming precipitation contributed to recharge of the aquifer (fig. 5), and water levels in all three wells began to climb dramatically; however, about a month passed before the level in the deepest well began to rise. Water levels continued to rise through summer 2003. During this period of rapidly rising water levels, the effects of individual recharge events are impossible to discern on the hydrograph (fig. 2).

The next obvious response of water levels to recharge occurred around April 1, 2004, when 1.68 in. of estimated recharge was produced by 1.69 in. of precipitation. The water levels in the two wells with shallower depths to water (MA-SDW 526-0040 and MA-SDW 527-0055) rose almost immediately, whereas water levels in the well with the greatest depth to water (MA-SDW 525-0109) showed little change in trend for about another month (fig. 2).

\section{Summary}

From January 2002 through December 2004, the USGS, in cooperation with the Army Environmental Center at the Massachusetts Military Reservation, measured water levels in three wells near the top of the water-table mound beneath western Cape Cod. The purpose of the measurements was to characterize the responses of the water levels as a function of the unsaturated-zone thickness. In January 2002, the region was in a drought, and the water-level hydrographs from the wells reflected the extremely dry period during most of 2002. During the first year of record, water levels in the three wells at the top of the water-table mound fell more than $2 \mathrm{ft}$. Water levels at a nearby well with 41 years of record declined to within a foot of the record-low level for the same period (1963-2004). As the water table declined, a change in the relative position of water-level altitudes in the three wells was recorded that supports a model-predicted northwest to southeast shift in the position of the top of the water-table mound during dry periods. The observed changes in altitude and position of the top of the water-table mound are related to changes in recharge from precipitation. Greater than normal precipitation brought increased recharge starting in Novem- 
Table 5. Estimated recharge determined from two daily soil-water balance approaches_Jensen and Haise (1963) and Thornthwaite (1948) - and annual precipitation at Otis Air National Guard Base, western Cape Cod, Massachusetts, 2002-04.

[in., inch; in/yr, inches per year]

\begin{tabular}{|c|c|c|c|c|c|c|c|}
\hline \multicolumn{6}{|c|}{ Recharge } & \multicolumn{2}{|c|}{ Precipitation } \\
\hline \multicolumn{2}{|c|}{ Calculation } & \multicolumn{4}{|c|}{ Annual recharge (in/yr) } & & \\
\hline $\begin{array}{c}\text { Method of potential } \\
\text { evapotranspiration (PET) } \\
\text { calculation }\end{array}$ & $\begin{array}{l}\text { Soil-moisture } \\
\text { capacity (in.) }\end{array}$ & 2002 & 2003 & 2004 & 3-year average & Year & $\begin{array}{l}\text { Annual precipi- } \\
\text { tation (in.) }\end{array}$ \\
\hline Jensen and Haise & 4 & 23.7 & 31.4 & 17.8 & 24.3 & 2002 & 40.4 \\
\hline Thornthwaite & 6 & 22.2 & 30.7 & 17.4 & 23.5 & mean & 42.7 \\
\hline
\end{tabular}

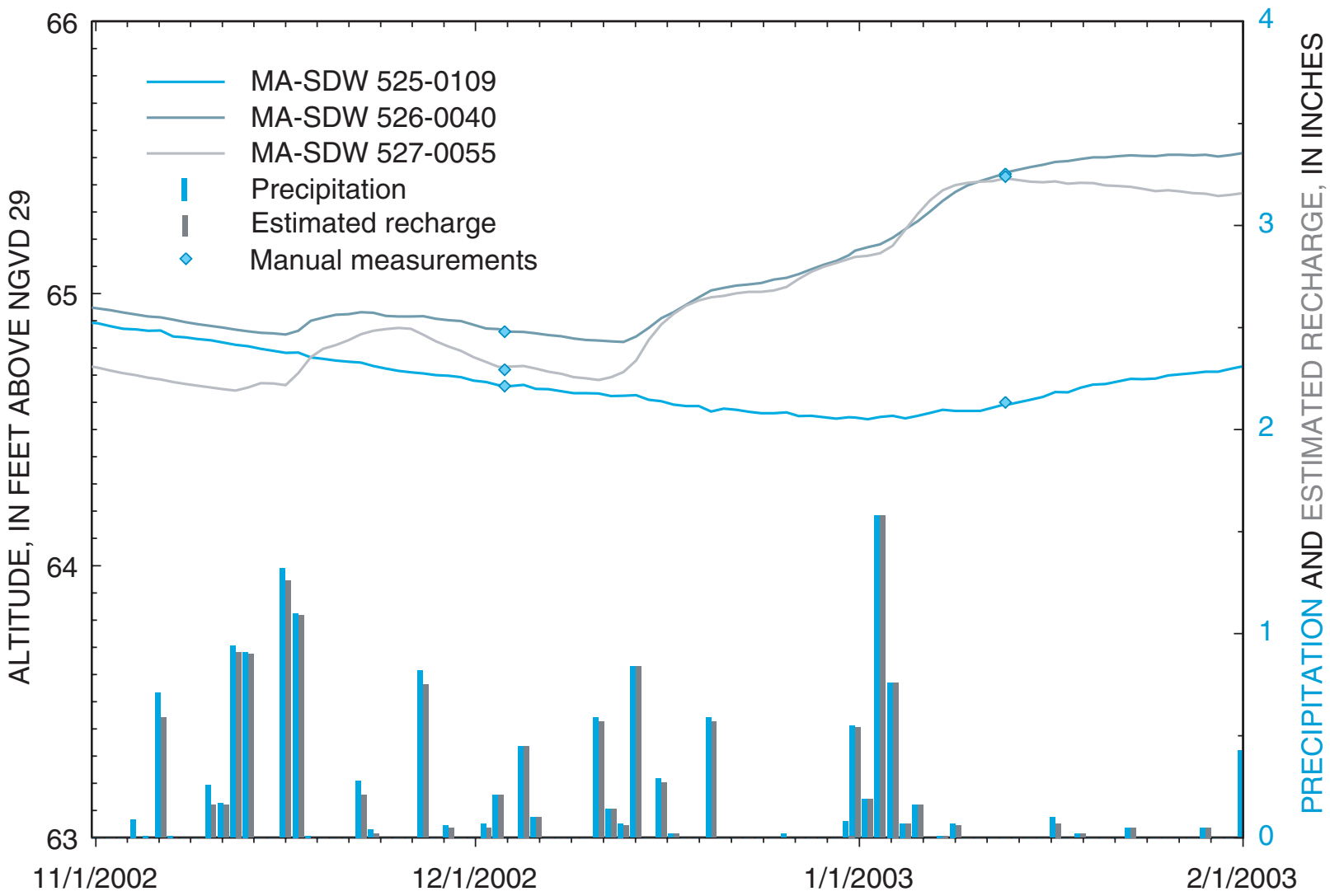

Figure 5. Continuous water levels recorded in three wells between the Southeast Ranges of Camp Edwards and Snake Pond, western Cape Cod, with bar graphs of precipitation and estimated recharge, November 2002 through January 2003. Daily precipitation was recorded at NOAA Weather Station KFMH at Otis Air National Guard Base, western Cape Cod, Massachusetts. 
ber 2002, which in turn caused the rise in water levels and a reversal in the relative water-table altitudes in the wells by September 2003. The responses of the water levels to individual precipitation events depended on the depth to water in the three wells, with the response in the well with the thickest unsaturated zone lagging about a month behind the response in the other two wells. This lag may reflect the effects of water movement through the thick unsaturated zone. The waterlevel information from this observation-well network provides valuable information on the dynamic ground-water system beneath the MMR.

\section{Acknowledgments}

The authors thank Timothy Dwyer and Thomas Remmers of Shaw Group (formerly of AMEC Earth \& Environmental, Inc.) for their assistance in providing access to the wells. We are grateful to Ronald Busciolano, U.S. Geological Survey Water Science Center, Coram, New York, and Roy Socolow, U.S. Geological Survey MA-RI Water Science Center, for their technical reviews, and Mary Ashman, U.S. Geological Survey MA-RI Water Science Center, for her editorial review; their reviews greatly enhanced this report. We also thank Rose Forbes of the Air Force Center for Environmental Excellence (AFCEE) Installation Restoration Program at the MMR for the use of one of the program's monitoring wells in this effort. Finally, we thank Benjamin Gregson and David Hill of the Army Environmental Center (AEC) of the Impact Area Groundwater Study Program (IAGWSP) for their support during this study.

\section{References}

Air Force Center for Environmental Excellence, 2003, Installation Restoration Program cleanup news, v. 3, no. 2: accessed on September 26, 2003, at http://www.mmr.org/ IRP/reports/cleanrep/jan2003.htm

Fassnacht, S. R., 2004, Estimating alter-shielded gauge snowfall undercatch, snowpack sublimation, and blowing snow transport at six sites in the conterminous United States: Hydrological Processes, v. 18, no. 18, p. 3481-3492.

Hamon, R.W., 1961, Estimating potential evapotranspiration: Proceedings of the American Society of Civil Engineers, Journal of the Hydraulic Division, v. 87, no. HY3, p. 107-120.

Hummel, P.R., Kittle, J.L., and Gray, M.H., 2001, WDMUtil-A tool for managing watershed modeling timeseries data, Version 2.0: U.S. Environmental Protection Agency, 157 p.
Jensen, M.E., and Haise, H.R., 1963, Estimating evapotranspiration from solar radiation: Proceedings of the American Society of Civil Engineers, Journal of Irrigation and Drainage, v. 89, no. IR4, p. 15-41.

LeBlanc, D.R., Guswa, J.H., Frimpter, M.H., and Londquist, C.J., 1986, Ground-water resources of Cape Cod, Massachusetts: U.S. Geological Survey HydrologicInvestigations Atlas HA-692, 4 pl.

Masterson, J.P., Walter, D.A., and LeBlanc, D.R., 1998, Delineation of contributing areas to selected public-supply wells, western Cape Cod, Massachusetts: U.S. Geological Survey Water-Resources Investigations Report 98-4237, $45 \mathrm{p}$.

National Climate Data Center, 2002, Monthly station normals of temperature, precipitation, and heating and cooling degree days, 1971-2000, 19-Massachusetts: Asheville, NC, National Oceanographic and Atmospheric Administration, National Climate Data Center, Climatography of the United States, no. 81, $16 \mathrm{p}$.

National Oceanic and Atmospheric Administration, 2005, National Weather Service Forecast Office, Boston, MA, recent daily climate data: accessed on April 5, 2005 at http://www.erh.noaa.gov/er/box//dailystns.shtml

Northeast Regional Climate Center, 2005, Daily data, East Wareham Coop Station, 1926-2004; Solar radiation data, KFMH 1997-2004; Daily from hourly data, KFMH, 1997-2004; and Daily precipitation data, KFMH, 1949-70; accessed on February 8, 2005 at www.nrcc@cornell.edu

Oldale, R.N., and Barlow, R.A., 1986, Geologic map of Cape Cod and the Islands, Massachusetts: U.S. Geological Survey Miscellaneous Investigations Series Map I-1763, 1 pl., scale $1: 100,000$.

Penman, H.L., 1948, Natural evapotranspiration from open water, bare soil, and grass: Proceedings of the Royal Society of London, Series A, v. 193, no. 1032, p. 120-145.

Ryan, B.J., 1980, Cape Cod aquifer, Cape Cod Massachusetts: U.S. Geological Survey Open-File Report 80-571, 36 p.

Strahler, A. N., 1972, The environmental impact of ground water use on Cape Cod-Impact study no. 3: Association for the Preservation of Cape Cod, Inc., Orleans, MA, 21 p.

Thornthwaite, C.W., 1948, An approach toward a rational classification of climate: Geographical Review, v. 38, p. 55-94.

Thornthwaite, C.W., and Mather, J.R., 1957, Instructions and tables for computing potential evapotranspiration and the water balance: Drexel Institute of Technology, Publications in Climatology, v. 10, no. 3, 311 p. 
Walter, D.A., and Masterson, J.P., 2003, Simulation of advective flow under steady-state and transient recharge conditions, Camp Edwards, Massachusetts Military Reservation, Cape Cod, Massachusetts: U.S. Geological Survey Water-Resources Investigations Report 03-4053, $51 \mathrm{p}$.

Walter, D.A., and Whealan, A.T., 2005, Simulated water sources and effects of pumping on surface and ground water, Sagamore and Monomoy Flow Lenses, Cape Cod, Massachusetts: U.S. Geological Survey Scientific Investigations Report 2004-5181, 85 p.

Willmott, C.J., 1977, WATBUG-A Fortran IV algorithm for calculating the climatic water budget: Publications in Climatology, v. 30, no. 2, p. 1-55. 
For additional information write to:

Director, USGS Massachusetts-Rhode Island Water Science Center 10 Bearfoot Road,

Northborough, MA 01532

or visit our Web site at

http://ma.water.usgs.gov 